\title{
Who pecks who in the world of English?
}

The New Oxford Dictionary of English (1998) says of the phrase pecking order (and its variant peck order) that it stands for 'a hierarchy of status among members of a group of people or animals, originally as observed among hens'. The Encarta World English Dictionary (1999) says of the same phrase (but without the variant peck order) that it is: (1) 'Soc Sci SOCIAL HIERARCHY a social hierarchy in which some members of a group are established as superior to others,' and (2) 'Birds SOCIAL HIERARCHY AMONG FOWL a social hierarchy among domestic fowl in which each member maintains its place by dominance over the lower members.'

It is intriguing that the editors of both volumes placed people before fowl: the fact that hens peck (as in hen-pecked) is for them of less immediate interest than the emergence of an analogy which allows us to say something that is far more socially potent about people than about chickens.

The matter is relevant in this issue of ET.

From time to time, over at least the last thirty years, commentators have been discussing hierarchy within the world's varieties of English. The Indian American scholar Braj B. Kachru has been noted, for example (from at least the early 1980s), for a model of English(es) that emphasizes multiplicity within the language across three world zones he calls the Inner, Outer, and Expanding Circles. In terms of these zones, native users of the language are 'Inner,' second-language users are 'Outer', and the rest of the planet is experiencing the Expansion.

Originally, and until about the mid-twentieth century, the UK was, as it were, pecker-in-chief. Within it, south-east England pecked the hardest, and the upper classes - wherever they lived - were so secure that others tended to do their pecking for them. In the course of the century, however, and especially after the Second World War (or rather, World War II), the size, strength, and influence of the US meant that its usage made inroads everywhere. As a result, the world looks far more nowadays towards (and listens far closer to) American than British (or any other usage), and this will continue indefinitely.

In this issue, however, the key commentator on such matters is not American or British or from mainland Europe or Australasia. He is West African, and markedly clear in what he has to say about his own country, Cameroon, and the world of English at large, however defined.

Tom McArthur

The editorial policy of English Today is to provide a focus or forum for all sorts of news and opinion from around the world. The points of view of individual writers are as a consequence their own, and do not reflect the opinion of the editorial board. In addition, wherever feasible, ET generally leaves unchanged the orthography (normally British or American) and the usage of individual contributors, although the editorial style of the journal itself is that of Cambridge University Press.

English Today (ISSN 0266-0784) is published quarterly by Cambridge University Press, The Edinburgh Building, Shaftesbury Road, Cambridge CB2 2RU, UK / Cambridge University Press, 40 West 20th Street, New York, N.Y. 10011-4211.

(c) Cambridge University Press 2006. No contents may be reproduced by any means without the permission of Cambridge University Press.

Subscriptions: The 2006 subscription price (excluding VAT) for four issues for libraries and institutions, which includes print and electronic access, is f98 outside of North America; $f 34$ for individuals; $f 25$ for students and the retired. The electronic-only price available to institutional subscribers is f86. Prices include delivery by air where appropriate. Apply to Jane Crossland at the above address.

Advertising Sales: write to the Advertising Promoter at the above address. Email:

journals_marketing@cup.cam.ac.uk

\section{USA, CANADA AND MEXICO:}

Subscriptions: The 2006 subscription price (excluding VAT) for four issues for libraries and institutions, which includes print and electronic access, is $\$ 164$ in USA, Canada and Mexico; \$54 for individuals; $\$ 39$ for students and the retired. The electronic-only price available to institutional subscribers is $\$ 140$. Apply to Marianne Headrick at Cambridge University Press,

40 West 20th Street, New York, N.Y. 10011-4211.

Advertising Sales: write to the Advertising Coordinator at the above address.

Periodicals postage paid at New York, NY and at additional mailing offices.

POSTMASTER: Send address changes to English Today, Cambridge University Press, 100 Brook Hill Drive, West Nyack, N.Y. 10994-2133.

Japanese prices for institutions are available from Kinokuniya Company Ltd, P.O. Box 55, Chitose, Tokyo 156, Japan.

Contacting the Editor: Email Dr Tom McArthur at <Scotsway@aol.com> or write to him at 22-23 Ventress Farm Court, Cherry Hinton Road, Cambridge CB1 8HD, UK. Tel 01223245934.

Internet access This journal is included in the Cambridge Journals Online service which can be found at http://uk.cambridge.org/journals. For further information on other Press titles access http://uk.cambridge.org.

Designed and typeset by Peter Ducker. Printed in the United Kingdom at the University Press, Cambridge. 